\title{
Study on Fish Ecology of the Seti Gandaki River Pokhara: II. Spatio-Temporal Variations in Fish Communities
}

\author{
K.K. Pokharel \\ Prithvi Narayan Campus, Tribhuvan University, Pokhara
}

\begin{abstract}
Present paper deals with the spatio-temporal variations in distribution and abundance of fishes along the $30 \mathrm{~km}$ stretch of the Seti Gandaki river and its two major tributaries, Mardi Khola and Vijaypur Khola, in Pokhara Valley, Western Nepal. A total of 30 species of fishes belonging to 5 orders, 9 families and 22 genera were recorded from five sites on the river and its tributaries. Cyprinoids were predominant among fishes (17 spp.), siluroids (5 spp.), balitorids and cobitids (4 spp.), channioids (2 spp.), belonoids (one sp.) and mastacembeloids (one sp.). Among cyprinoids, mostly cyprinines were dominant groups (7 spp.) followed by rasborines (7 spp.), garrines ( $2 \mathrm{spp}$.) and schizothoracines (one sp.). There was increasing trend of species richness at upstream site (17 spp.). to downstream site (20 spp.) showing a longitudinal pattern. The total fish abundance and family-wise abundance at all the sites observed major peak during the spring and fall during the winter season in both the years of study. The average total density of fishes during the spring peak was highest (51.07/ha) at the upper tributary site and lowest (24.69/ha) at the urban site. According to the distribution pattern and abundance, the population status of the gamefish, mahseer [Tor tor (Ham)] has been endangered (E); that of game fishes [Tor putitora (Ham.) and Chagunius chagunio (Ham.)] and Zebra-fish [Brachydanio rerio (Ham.)] to are vulnerable (V); that of loach [Lepidocephalus guntea (Ham.)], cat-fishes [Myersglanis blythii (Day) and Amblyceps mangois (Ham.)] are rare (R).
\end{abstract}

Key words: fish ecology, spatio-temporal variations, fish communities, the Seti Gandaki river

\section{Introduction}

Pokhara valley, a place of natural paradise, is situated in Western Region of Nepal having many fascinating water resources-river, streams, creeks, lakes and ponds, so, known as, "water resources valley of Nepal”. It covers an area of about 200 sq. km., extending between $25^{\circ} 07^{\prime}$ and $28^{\circ} 10^{\prime} \mathrm{N}$ Latitude and $83^{\circ} 50^{\prime}$ and $84^{\circ} 50^{\prime} \mathrm{E}$ Longitude and lies above $800 \mathrm{~m}$ asl (Tripathi 1985). It is extended north-west to south-east for $25 \mathrm{~km}$ and varies north to south between 8 to $15 \mathrm{~km}$. The physiographic features of this valley are diverse due to presence of river, streams, lakes, caves, terraces, deep gorges, steep slopes and bounded by high Mahabharat and Himalyan ranges to its northern side. The lotie water bodies in Pokhara valley are the Seti Gandaki river and its tributaries. The river originates near the base of Mount Machhapuchhre (6,997m) and Mount Annapurna $(7,525 \mathrm{~m})$ flowing downwards receives several tributaries and passes through the heart of Pokhara valley (Fig. 1) forming deep gorges. The catchment area of this river is about $600 \mathrm{sq}$. km, and a total length of about $112.6 \mathrm{~km}$. It joins the Trishuli river at Gaighat (Sharma 1977). The major tributaries 
of this river are Mardi Khola and Vijaypur Khola. Mardi Khola, a snow-fed stream, originates from Mardi Himal $(5,127 \mathrm{~m})$ extending about $25 \mathrm{~km}$ in length, flows downwards and joins the Seti Gandaki river near Lahachok, about $15 \mathrm{~km}$ from the Pokhara city area. Vijaypur Khola, a spring-fed stream, arises at the foothills of Mahabharat range situated in the north-eastern side of the valley and is about $12 \mathrm{~km}$ in length. It flows downwards through the eastern part of the valley and joins the Seti Gandaki river about $13 \mathrm{~km}$ from the city area.

Ecological studies conducted on rivers and streams mostly included physico-chemical parameters but biological parameters were given little attention. So, river ecologists have also suggested the importance of biological monitoring of water bodies (Nikolsky 1963, Shrestha 1990, Allan 1995, Dudgeon 1999).

Fishes are important aquatic fauna serving as food, entertainment, biological control agents, animal feed, manure, decoration, sports, etc to human beings from the time immemorial. The lotic water bodies of the valley are the habitat, of several species of fishes.

Literature on fish species-diversity of Nepal include the works of Hamilton (1822) who was probably the first ichthyologist to give an authentic information of fishes of Nepal. Afterwards, Gunther (1861), Day (1878), Reagan (1907), Mukherjee (1931), Hora (1937), Menon (1949), Taft (1955), Dewitt (1960), Thapa and Rajbanshi (1968), Majumdar et al, (1972) and Shrestha (1981, 1994, 2001) reported fishes of Nepal. Similarly, Shrestha (1981, 1990), Rajbanshi (1982), Terashima (1984), Edds (1985, 1986), FRD (1994), Majupurias (1998), NARC and JICA (1998), Rai (2005), Swar (2005) and Majupurias (2006) reported fish and fisheries of Nepal.

Works on fish species-diversity and fisheries of Pokhara valley are those of Ferrow and Badgami (1980); Swar and Gurung (1988); John and Dhewajoo (1989); FRC (1992) and Pokharel (1998, 1999, 2006), who reported fishes of rivers, streams and lakes.

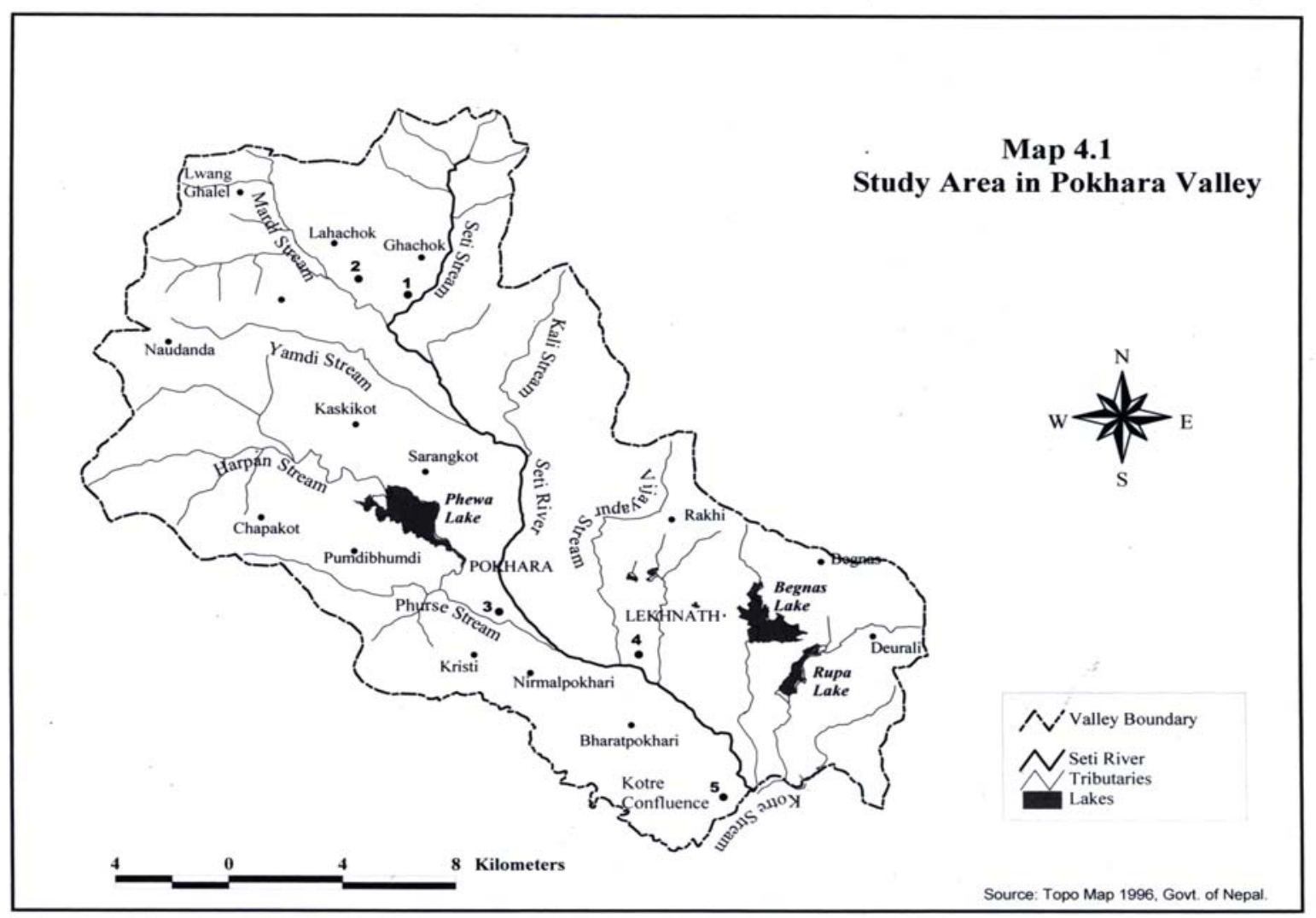




\section{Study Area}

The study sites are situated at different places along the lotic water bodies - the Seti Gandaki river and its tributaries (Fig. 1). Five sites were selected of which three on the Seti Gandaki river and two on its major tributaries, Mardi Khola and Vijayapur Khola, which are as follows:

\section{Site 1: Lahachok area (Pre-urban Site)}

The uppermost sampling site was in the main channel near the Lahachok village, about $19.5 \mathrm{~km}$ upstream from the urban or third site. The river banks on both the sides were erosion-sensitive and the watershed area had patchy forests, grasslands, agricultural fields and cremation spots. The river-bed had less sand and pebbles, but with more stones and boulders.

\section{Site 2: Mardi Khola/stream (Upper tributary site)}

This site was situated above the confluence of the Mardi stream with the Seti Gandaki river near Mardi about $19 \mathrm{~km}$ upstream from the urban or third site. It also had erosion-sensitive banks and the watershed area had forests, agricultural fields and village area. The stream-bed had less sand and gravels, but with more stones and boulders.

\section{Site 3: Dobilla (Urban site)}

The third site or urban site was situated near Dobilla, the south-western point of Pokhara valley below the lower part of densely populated city area and $4 \mathrm{~km}$ upstream from the fourth site. The watershed included the village area, grasslands, agricultural fields, municipal area and cremation spots. The municipal wastes, industrial wastes and agricultural wastes directly entered into the river through canals. River bed had sand, pebbles, gravels, stones and boulders.

\section{Site 4: Vijaypur Khola (Lower tributary site)}

This site was on Vijaypur Khola, located about $5.5 \mathrm{~km}$ upstream from the fifth site and $0.5 \mathrm{~km}$ from the confluence of this stream with the Seti Gandaki river. The banks were heavily eroded. The watershed area had agricultural fields, poultry farms and village area. The surface run-off from watershed area as well as the human activities such as bathing, washing of various items including vehicle released chemical substances into the water. Steam-bed was covered with pebbles, stones and boulders with less sand.

\section{Site 5: Kotre area (Post-urban site)}

The fifth site was on the main channel near Kotre in Tanahun district (the district boundary between Kaski and Tanahun districts) about $20 \mathrm{~km}$ south-east from Pokhara city. The watershed area had agricultural fields, Lekhnath municipality area, villages and cremation spots. The surface run-off from the above area carried dissolved chemical substances released from chemical fertilizers, pesticides and ashes which enter into the river. The river-bed had sand, gravels, stones and boulders.

\section{Methodology}

Fish sampling was done monthly and samples required for further study were collected from five sites, three on the Seti Gandaki river and two on its tributaries (one on Mardi Khola - upper tributary, and one on Vijaypur Khola - lower tributary) from September 2001 to August 2003.

Fishes were sampled at each site with the help of a cast-net (mesh 6mm) by an experienced fisherman following the techniques of Ricker (1968) and APHA (1998), For estimation of distribution and abundance of fishes, two - pass removal method (Seber and Le Cren 1967) was used. Each removal pass included moving first upstream and then downstream within a predetermined length (100 $\mathrm{m}$ ) having six sub-sections of river / stream. The surface area of these sub - sections of river / stream was estimated using width and length of the sampled area. Sampling was performed with equal effort (time - half an hour) for each pass at each site to catch maximum number and species of fishes. The fishes were caught, examined and released unharmed into the water after identification and recording required data. The specimens, which required taxonomic verification, were collected and preserved in $10 \%$ buffered formalin and brought to the laboratory. Fishes were identified with the help of taxonomic monographs of Day (1878), Jayaram (1981) and Shrestha (1981, 2001). The abundance of fish was expressed as number per 0.1 ha. The criteria laid out by IUCN (1994) were followed for assessment of the status of fishes.

\section{Results}

Seasonal variations in number and percentage abundance of different families of fishes at various 
Nepal Journal of Science and Technology 12 (2011) 350-357

sampling sites for a period of two years are presented in Tables 1 to 5 . A total of 30 species of fishes belonging to 5 orders, 9 families and 22 genera were recorded from the five sites on the Seti Gandaki river and its two major tributaries, Mardi Khola and Vijaypur Khola which are listed in Table 6.

Table 5. Mean Seasonal variations in number and percentage abundance of fishes at Post-urban Site/Site - 5 of Seti Gandaki river, during 2001-2003.

\begin{tabular}{|c|c|c|c|c|c|c|c|c|c|c|}
\hline \multirow{3}{*}{$\begin{array}{l}\text { Season } \\
\text { Taxa }\end{array}$} & \multicolumn{10}{|c|}{ No. 0.1ha' ${ }^{-1}$. } \\
\hline & \multicolumn{2}{|c|}{ Autumn (Sep.-Nov.) } & \multicolumn{2}{|c|}{ Winter (Dec.-Feb.) } & \multicolumn{2}{|l|}{$\begin{array}{l}\text { Spring } \\
\text { May) }\end{array}$} & \multicolumn{2}{|c|}{$\begin{array}{l}\begin{array}{l}\text { Summer } \\
\text { Aug.) }\end{array} \\
\end{array}$} & \multicolumn{2}{|l|}{ Average } \\
\hline & No. & $\%$ & No. & $\%$ & No. & $\%$ & No. & $\%$ & No & $\%$ \\
\hline \multicolumn{11}{|l|}{ Cyprininae } \\
\hline Neolissocheilus hexagonolepis & 16.50 & 6.35 & 6.16 & 4.34 & 23.33 & 6.22 & 10.66 & 5.58 & 14.16 & 5.85 \\
\hline Tor putitora & 8.33 & 3.20 & 3.00 & 2.11 & 16.50 & 4.39 & 6.33 & 3.31 & 8.59 & 3.53 \\
\hline T. tor & 6.16 & 2.37 & 2.00 & 1.41 & 8.33 & 2.22 & 4.00 & 2.09 & 5.12 & 2.11 \\
\hline Chagunius chagunio & $\begin{array}{l}8.49 \\
(91.81)\end{array}$ & $\begin{array}{l}3.26 \\
(35.34)\end{array}$ & $\begin{array}{l}4.00 \\
(44.49)\end{array}$ & $\begin{array}{l}2.82 \\
(31.41)\end{array}$ & $\begin{array}{l}14.16 \\
(133.48)\end{array}$ & $\begin{array}{l}3.77 \\
(35.58)\end{array}$ & $\begin{array}{l}6.16 \\
(66.97)\end{array}$ & $\begin{array}{l}3.22 \\
(35.07)\end{array}$ & $\begin{array}{l}8.20 \\
(84.17)\end{array}$ & $\begin{array}{l}3.39 \\
(34.81)\end{array}$ \\
\hline B. barila & 7.33 & 2.82 & 3.00 & 2.11 & 11.83 & 3.15 & 5.00 & 2.61 & 6.79 & 2.80 \\
\hline B. barna & $\begin{array}{l}6.33 \\
(55.64)\end{array}$ & $\begin{array}{l}2.43 \\
(21.42)\end{array}$ & $\begin{array}{l}2.00 \\
(32.16)\end{array}$ & $\begin{array}{l}1.41 \\
(22.70)\end{array}$ & $\begin{array}{l}8.33 \\
(90.32)\end{array}$ & $\begin{array}{l}2.22 \\
(24.08)\end{array}$ & $\begin{array}{l}5.00 \\
(43.99)\end{array}$ & $\begin{array}{l}2.61 \\
(23.04)\end{array}$ & $\begin{array}{l}5.41 \\
(55.52)\end{array}$ & $\begin{array}{l}2.23 \\
(22.96)\end{array}$ \\
\hline \multicolumn{11}{|l|}{ Garrinae } \\
\hline Garra annandalei & 8.33 & 3.20 & 4.00 & 2.82 & 15.33 & 4.08 & 6.33 & 3.31 & 8.49 & 3.51 \\
\hline G. gotyla & $\begin{array}{l}24.49 \\
(32.82)\end{array}$ & $\begin{array}{l}9.42 \\
(12.63)\end{array}$ & $\begin{array}{l}16.50 \\
(20.50)\end{array}$ & $\begin{array}{l}11.65 \\
(14.47)\end{array}$ & $\begin{array}{l}37.83 \\
(53.16)\end{array}$ & $\begin{array}{l}10.08 \\
(14.17)\end{array}$ & $\begin{array}{l}18.66 \\
(24.99)\end{array}$ & $\begin{array}{l}9.77 \\
(13.08)\end{array}$ & $\begin{array}{l}24.37 \\
(32.86)\end{array}$ & $\begin{array}{l}10.07 \\
(13.59)\end{array}$ \\
\hline \multicolumn{11}{|l|}{ Schizothoracinae } \\
\hline Schizothorax richardsonii & $\begin{array}{l}8.33 \\
(8.33) \\
{[188.60]}\end{array}$ & $\begin{array}{l}3.20 \\
(3.2) \\
{[72.61]}\end{array}$ & $\begin{array}{l}2.00 \\
(2.00) \\
{[99.15]}\end{array}$ & $\begin{array}{l}1.41 \\
(1.41) \\
{[70.01]}\end{array}$ & $\begin{array}{l}13.00 \\
(13.00) \\
{[289.96]}\end{array}$ & $\begin{array}{l}3.46 \\
(3.46) \\
{[77.30]}\end{array}$ & $\begin{array}{l}6.33 \\
(6.33) \\
{[142.28]}\end{array}$ & $\begin{array}{l}3.31 \\
(3.31) \\
{[74.52]}\end{array}$ & $\begin{array}{l}7.41 \\
(7.41) \\
{[179.96]}\end{array}$ & $\begin{array}{l}3.06 \\
(3.06) \\
{[74.43]}\end{array}$ \\
\hline \multicolumn{11}{|l|}{ Bagridae } \\
\hline Mystus bleekeri & $\begin{array}{l}11.83 \\
{[11.83]}\end{array}$ & $\begin{array}{l}4.55 \\
{[4.55]}\end{array}$ & $\begin{array}{l}9.49 \\
{[9.49]}\end{array}$ & $\begin{array}{l}6.70 \\
{[6.70]} \\
\end{array}$ & $\begin{array}{l}12.99 \\
{[12.99]}\end{array}$ & $\begin{array}{l}3.46 \\
{[3.46]}\end{array}$ & $\begin{array}{l}8.33 \\
{[8.33]}\end{array}$ & $\begin{array}{l}4.36 \\
{[4.36]}\end{array}$ & $\begin{array}{l}10.66 \\
{[10.66]}\end{array}$ & $\begin{array}{l}4.40 \\
{[4.40]}\end{array}$ \\
\hline \multicolumn{11}{|l|}{ Belonidae } \\
\hline Xenentodon cancila & $\begin{array}{l}8.33 \\
{[8.33]}\end{array}$ & $\begin{array}{l}3.20 \\
{[3.20]}\end{array}$ & $\begin{array}{l}8.33 \\
{[8.33]}\end{array}$ & $\begin{array}{l}5.88 \\
{[5.88]}\end{array}$ & $\begin{array}{l}10.66 \\
{[10.66]}\end{array}$ & $\begin{array}{l}2.84 \\
{[2.84]}\end{array}$ & $\begin{array}{l}6.16 \\
{[6.16]}\end{array}$ & $\begin{array}{l}3.22 \\
{[3.22]}\end{array}$ & $\begin{array}{l}8.37 \\
{[8.37]}\end{array}$ & $\begin{array}{l}3.46 \\
{[3.46]}\end{array}$ \\
\hline \multicolumn{11}{|l|}{ Channidae } \\
\hline Channa orientalis & 13.00 & 5.00 & 7.33 & 5.17 & 14.16 & 3.77 & 8.49 & 4.44 & 10.74 & 4.44 \\
\hline C. punctatus & $\begin{array}{l}8.33 \\
{[21.33]}\end{array}$ & $\begin{array}{l}3.20 \\
{[8.21]} \\
\end{array}$ & $\begin{array}{l}4.00 \\
{[11.33]}\end{array}$ & $\begin{array}{l}2.82 \\
{[8.00]}\end{array}$ & $\begin{array}{l}9.49 \\
{[23.65]}\end{array}$ & $\begin{array}{l}2.53 \\
{[6.30]}\end{array}$ & $\begin{array}{l}6.00 \\
{[14.49]}\end{array}$ & $\begin{array}{l}3.14 \\
{[7.58]} \\
\end{array}$ & $\begin{array}{l}6.95 \\
{[17.69]}\end{array}$ & $\begin{array}{l}2.87 \\
{[7.31]} \\
\end{array}$ \\
\hline \multicolumn{11}{|l|}{ Mastacembelidae } \\
\hline Mastacembelus armatus & $\begin{array}{l}11.83 \\
{[11.83]} \\
\end{array}$ & $\begin{array}{l}8.33 \\
{[8.33]} \\
\end{array}$ & $\begin{array}{l}6.16 \\
{[6.16]} \\
\end{array}$ & $\begin{array}{l}4.34 \\
{[4.34]} \\
\end{array}$ & $\begin{array}{l}15.33 \\
{[15.33]} \\
\end{array}$ & $\begin{array}{l}4.08 \\
{[4.08]} \\
\end{array}$ & $\begin{array}{l}8.33 \\
{[8.33]} \\
\end{array}$ & $\begin{array}{l}4.36 \\
{[4.36]} \\
\end{array}$ & $\begin{array}{l}10.41 \\
{[10.41]}\end{array}$ & $\begin{array}{l}4.30 \\
{[4.30]} \\
\end{array}$ \\
\hline Total & 259.74 & - & 141.62 & - & 375.07 & - & 190.92 & - & 241.78 & \\
\hline
\end{tabular}

Numbers inside the parenthesis [ ] indicate the familywise and ( ) indicate the sub-familywise total and percentage abundance. 
Cyprinoids (carps, minor carps, carp-minnows, suckerheads and snow-trouts) were pre-dominant among fishes (17 species), followed by siluroids (5 species), loaches (4 species), gar fishes (1 species), snakeheads (2 species) and spiny eels (1 species). Among cyprinoids, mostly the cyprinines (carps and minor carps) were recorded to be dominant groups (7 species) followed by rasborines (carp-minnows / hill-trouts) (7 species), garrines / suckerheads) (2 species) and schizothoracines (snow-trouts) (1 species).

There was increasing trend of species richness at upstream site (Site 1) (17 species) to downstream site (Site 5) (20 species) in the present water bodies, showing a longitudinal pattern.

The total fish abundance as well as familywise abundance at all the sites observed major peaks during the spring season and fall during winter season in both the years of investigation. The average total density of fishes during the spring peak was highest (510. 70/0.1 ha) at the upper tributary site (site 2) and lowest (246.95/0.1 ha) at the urban site (site 3). This peak was mainly due to the family Cyprinidae.

The average density of cyprinoids was highest (225.68/ 0.1 ha) at site 4 and lowest (119.84/0.1 ha) at site 3 . The contribution of cyprinoids to total fish population gradually declined in summer / monsoon and winter seasons. Among cyprinines, Neolissocheilus hexagonolepis, Puntius sophore and $P$. conchonius had 4.32, 6.64 and 7.10 in site 4 and 4.40, 3.83 and 5.25 in site 3 , and among rasborines Barilius bendelisis and B. vagra had 12.91 and 10.78 in site 4 and 14.04 and 5.16 in site 3 as percentage (\%) abundance and were dominant species at most of the sites. Similarly, the balitorids (hill-stream loaches) had highest density (35.78/0.1 ha) at site 4 and lowest (12.99/0.1 ha) at site 3 . The contribution of balitorids to the total fish density declined till the end of summer/ monsoon season, then increased in autumn at the main channel sites, whereas it increased from spring till the end of autumn at the tributary sites. Among balitorids, Acanthocobatis botia and Schistura beavani had 8.92 and 2.72 respectively at site 4 and 7.74 at site 3 as percentage abundance and were dominant species.

The channioids (snake heads) had highest density (23.39/0.1 ha) at site 3 and lowest (12.12/0.1 ha) at site 1 . The contribution of channoids to total fish density gradually declined in summer/monsoon season and winter season. Channa orientalis and C. punctatus had 6.89 and 7.04 respectively at site 3 and 4.04 at site 1 as percentage abundance. Likewise, the mastacembeloids (spiny-eels) had highest density (12.45/0.1 ha) at site 1 and lowest (9.78/0.1 ha) at site 4 . The contribution of the mastacembeloid, Mastacembelus armatus to total fish population which had 4.15 at site 1 and 3.18 at site 4 as percentage abundance also declined in summer / monsoon and winter seasons.

The sisorids (hill-stream cat-fishes) had highest density (36.52/0.1 ha) at site 2 and lowest (8.41/0.1 ha) at site 4 . The contribution of the sisorids, Pseudecheneis sulcatus, Myersglanis blythii and Glyptothorax pectinopterus to total fish density which had 4.57, 2.57 and 4.48 respectively at site 2 and 2.73 (Glyptothorax) at site 4 as percentage abundance, also declined in summer/monsoon and winter seasons. Similarly, the amblycipitids (hill-stream cat-fishes) had highest density (5.45/0.1 ha) at site 2 and lowest (4.87/ 0.1 ha) at site 1 . The contribution of the amblycipitid, Amblyceps mangois to total fish population which had 1.69 at site 2 and 1.62 at site 1 as percentage abundance, also declined in summer/monsoon and winter seasons.

The belonoids (stony-eels) had highest density (11.57/ 0.1 ha) at site 4 and lowest (8.37/0.1 ha) at site 5. The contribution of the belonoid, Xenentodon canclia to total fish density which had 3.76 at site 4 and 3.46 at site 5 as percentage abundance, also declined in summer/monsoon and winter seasons. In the same way, the cobitids (hill-stream loaches) had density as 5.37/ 0.1 ha at site 2 . The contribution of the cobitid, Lepidocephalus guntea to total fish density which had 1.66 at site 2 as percentage abundance, also declined in summer/monsoon and winter seasons. Likewise, the bagrids (catfishes) had 10.66/0.1 ha at site 5. The contribution of the bagrid, Mystus bleekeri to the total density which had 4.40 as percentage abundance, also declined during summer/monsoon and winter seasons.

According to the distribution pattern and abundance, the population status of the popular game fish, mahseer (Tor tor) was found to be endangered (E); that of important game fishes (Tor putitora and Chagunius chagunio) and Zebra-fish (Brachydanio rerio) to be vulnerable (V); and that of hill-stream loach 
(Lepidocephalus guntea), hill-stream cat fishes (Myersglanis blythii and Amblyceps mangois) to be rare (R) (Table 6) (Shrestha, 2001).

Significant human activities observed at the above mentioned sites were extraction of sand and stones, breaking the boulders, movement of heavy vehicles for transportation of extracted materials, electro-fishing and introduction of chemicals/ pesticides for fishing (poisoning the water) near some sites (sites 3 and 4). The above activities certainly alter the abiotic as well as biotic components of water.

\section{Discussion}

Cyprinoids (carps, minor carps, carp minnows, suckerheads and snow trouts) have been reported to be dominant among fishes, followed by loaches, siluroids (hill stream catfishes), snake-heads, spinyeels and gar-fishes. Among cyprinoids, mostly the cyprinines (carps and minor carps) were observed to be dominant groups followed by rasborines (carp minnows / hill-trouts), garrines (suckerheads) and schizothoracines (snow trouts) (Edds 1993, Pokharel 1999, Champasri 2003). Likewise, the cyprinines (carps and minor carps) and rasborines (carp minnows / hilltrouts) have been mentioned to contribute to a major portion of the fish biota (Edds 1993, Pokharel 2006, Shrestha 2001, Swar 2005). Similar pattern of species composition, family and group dominance was observed in the present work and also the important species, Neolissocheilus hexagonolepis, Puntius sophore, P. conchonius, Barilius bendelisis, Garra gotyla and Schizothorax richardsonii were found to be dominant forms at most of the study sites. The above mentioned species composition, group dominance and species dominance could be attriduted to complex physio-hydrological characterictics as well as in part to zoogeographical factors regarding the dispersal and dominance of Himalayan fishes, from the oriental realm, and Central Asia, after the early Tertiary upheavals that created these mountains and during interglacial periods of the Pleistocene respectively (Menon 1954, 1955, Edds 1993).

Edds (1993), (FRC 1992), Williams et al. (1996) and Kouamelan et al. (2003) mentioned increasing trend of species richness at upstream to downstream sites in various riverine water bodies. In the present study, the species richness of fishes was also observed in similar longitudinal pattern, which could be attributed to the diverse physiography with river-bank / bed heterogeneity, water velocity and discharge, gradient and depth, temperature and turbidity, various physicochemical characterisitics and biotic inter-relationships of fishes, which constitute different ecological niches that fulfill the biological needs of the fish biota.

Livingson et al. (1991) and Kouamelan et al. (2003) reported higher species richness and abundance at main stem section of Choctawhatichee River system, Florida, USA and in West African basin, Ivory Coast, than at the tributary sites. However, Dobriyal and Joshi (1999) mentioned lower species richness in Mandakini river, Garhwal, India, than in its tributary, Nayar Stream. In the present study, the species richness values were lower at the upper and middle reaches but were higher at the lower reach in comparison to those of tributary sites, which could be attributed to habitat variation, physico-chemical properties and hydro-biological characteristics.

Various investigators such as, Edds et al. (2002) and Nislow et al. (2002) reported higher species richness and abundance during spring / summer season and lower during winter season in various lotic water bodies. In the present study, the temporal variations in species richness and abundance were similar to the above mentioned observations, which could be attributed to the seasonal climatic conditions that markedly change the hydrological regime, physicochemical characteristics and biotic communities.

\section{Acknowledgements}

The researcher is obliged to Prof. K. Basnet, Central Department of Zoology, Tribhuvan University and Prof. T.C. Majupuria, formerly Central Department of Zoology, Tribhuvan University for their suggestions and encouragement. I am thankful to Mr. P.J. Shah, Head Department of Zoology, Prithiwi Narayan Campus, (PNC), Pokhara for providing the necessary facilities. I am grateful to Prof. D.R. Edds, Department of Biological Sciences, Emporia State University, USA and Mr. R.G. Dhewajoo, Reader, P.N. Campus, Pokhara for their valuable suggestions and appreciation. Thanks are also due to Mr. B.R. Pahari, Mr. R. Pandey, Mr. O.L. Jalari, P.N. Campus and Mr. K.L.Jalari, Nadipur, Pokhara for assistance in the laboratory and field work. 
I express grateful thanks to Deans Office, Institute of Science and Technology T.U., Kathmandu for providing research grant to perform the present work.

\section{References}

Allan, J.D. 1995. Stream ecology: Structure and function of running waters. Kluwer Academic Publishers, Dordrecht, The Netherlands. 388 pp.

APHA/AWWA/WEF. 1998. Standard methods for the examination of water and wastewater (20th Edition). American Public Health Association (APHA), American Water Works Association (AWWA) and Water Environment

Federation (WEF), Washington DC, USA. 10 - 157 and 1 49 pp.

Champasri, T. 2003. Some ecological aspects, water properties and natural fish species of the Phrom river in North-East Thailand. Pakistan Journal of Biological Sciences 6 (1) : 65-69.

Day, F. 1878. The fishes of India, being a natural history of the fishes known to inhabit the seas and freshwaters of India, Burma and Ceylon. Vol I and II. Reprint by Today and Tomorrow's Book Agency, New Delhi. 517 pp.

Dewitt, H.H. 1960. A contribution to the ichthyology of Nepal. Stanford Ichthyological Bulletin 7 (4) : 63 - 68.

Dobriyal, A.K. and H. Joshi 1999. Faunal diversity and its determinant factors in some hill streams of Garhwal Himalaya. Uttar Pradesh Journal of Zoology 19 (1) : 85-87.

Dudgeon, D. 1999. Tropical Asian streams : Zoobenthos, ecology and conservation. Hong Kong University Press, Aberdeen, Hong Kong. 830 pp.

Edds, D.R. 1985. New records of fish species for Nepal. Journal of the Natural History Museum 9 : 41 - 46.

Edds, D.R. 1986. Fishes of the Kali Gandaki / Narayani River, Nepal. Ibid 10 (1 - 4) : 13 - 22.

Edds, D.R. 1993. Fish assemblage structure and environmental correlates in Nepal's Gandaki River. Copeia 1993 (1) : 48 - 60.

Edds, D.R., D.P. Gilette, T.M. Maskey and M. Mahato 2002. Hot - soda process paper mill effluent effects on fishes and macroinvertebrates in the Narayani River, Nepal. Journal of Freshwater Ecology 17 (4) : 543 - 554.

Ferrow, W. and P.R. Badgami, 1980. On the biology of the commercially important species of fish of the Pokhara valley, Nepal, Journal of Institute of Science 3 (1) : 237 250 .

FRC. 1992. Preliminary study of Harpan Khola and Mardi Khola. Annual technical report-1991-1992, Fisheries Research Centre, Pokhara, Nepal. 12 pp.

FRD. 1994. Fish specimen collection and their taxonomic study. Annual report-1993-1994. Fisheries Research Division, Godavari, Lalitpur, Nepal. 19 pp.
Gunther, A.G. 1861. List of cold - blooded vertebrates collected by B.H. Hodson, in Nepal. Proceedings of Zoological Society of London : 213 - 227.

Hamilton, F.B. 1822. An account of the fishes found in the river Ganges and its Branches. VII. Edinburgh, UK. 405 pp.

Hora, S.L. 1937. Notes of fishes in the Indian museum, XXIX. on a collection of fish from Nepal. Records of Indian museum 39 : 43 - 45.

IUCN. 1994. IUCN red list categories. International Union for the Conservation of Nature and Natural Resources, Gland, Switzerland.

Jayram, K.C. 1981. The freshwater fishes of India - A hand book. Zoological Survey of India, Calcutta, India. 475 pp.

John, A. and R.G. Dhewajoo 1989. Effect of ecological parameters on fishes of Pokhara valley. A report, submitted to Royal Nepal Academy of Science and Technology, Kathmandu. 36-39 pp.

Kouamelan, E.P., G.G. Teugels, V. N’ Doyba, G. Bi Goore, and T. Kone 2003. Fish diversity and its relationships with environmental variables in a West African basin. Hydrobiologia 505 : 139 - 146.

Livingston, R.J., J.H. Epler, F. Jordan Jr., W.R. Karsteter, C.C. Koenig, A.K.S.K. Prasad and G.L. Ray 1991. Ecology of te Choctawhatchee river system. In: The Rivers of Florida. Ed. R.J. Livingston. Springer-Verlag, New York. pp. 247-274.

Majumdar, N.N., T.C. Majupuria and J. Shrestha 1972. New records of fish faunna from Nepal. Journal of Zoological Society of India No .2 : 213-215.

Majupuria, T.C. and R.K. Majupuria 1998. Wildlife, national parks and reserves of Nepal (resources and management). S. Devi, Bajoria Road, Opposite Saharanpur Club, Saharanpur, India. 427 pp.

Majupuria, T.C., and R.K. Majupuria 2006. Wildlife and protected areas of Nepal (resources and management). S.Devi, Bajoria Road, Opposite Saharanpur Club, Saharanpur, India. 549 pp.

Menon, A.G.K. 1949. Notes on fishes in the Indian museum, XLIV. Fishes from the Koshi Himalayas, Nepal. Records of Indian Museum $47: 231$ - 237.

Menon, A.G.K. 1954. Fish geography of the Himalayas. Proceedings of National Institute of Science 20 : 467 493.

Menon, A.G.K. 1955. The external relationships of the Indian freshwater fishes, with special reference to the countries bordering on the Indian ocean. Journal of Asiatic Sciences 21 : 31-38.

Mukherjee, D.D. 1931. The generic position of the Nepalese fish Dipticus annandalei Reagan. Records of Indian museum $33: 63$ - 65 .

NARC/JICA. 1998. Present status of fisheries research, development and education in Nepal. Nepal Agricultural Research Council and Japanese International Cooperation Agency. 1998. Lalitpur, Nepal. 170 pp. 
Nepal Journal of Science and Technology 12 (2011) 350-357

Nikolsky, G.V. 1963. The ecology of fishes. Academic Press, London. 352 pp.

Nislow, K.H., F.J. Magilligan, C.L. Folt and B.P. Kennedy 2002. Within-basin variation in the short - term effects of a major flood on stream fishes and invertebrates. Journal of Freshwater Ecology 17(2) : 305 - 318.

Pokharel, K.K. 1998. Fishery resources of Harpan stream and their need of conservation. Natural History Society of Nepal Bulletin 8 (1-4) : 18 - 25.

Pokharel, K.K. 1999. Studies on fisheries resources of Seti river and Vijaypur stream in Pokhara valley, their structural modifications and need for conservation. A report, Submitted to Dean's Office, Institute of Science and Technology, Tribhuvan University, Kathmandu. 64 pp.

Pokharel, K.K. 2006. Fisheries resources of river and streams in Pokhara Valley, Nepal : Urgent need of conservation and sustainable utilization. In: Proceedings of Fourth National Conference on Science and Technology Vol. 1. Nepal Academy of Science and Technology, Khumaltar, Lalitpur. pp 315-331

Rai, A.K. 2005. Potential of indigenous riverine fish species in Nepal. Fisheries Research Division, Godavari, Lalitpur, Nepal.

Rajbanshi, K.G. 1982. General bibliography of fish and fisheries of Nepal. Royal Nepal Academy, Kathmandu. 99 pp.

Rao, R.J. 2001. Biological resources of the Ganga river, India. Hydrobiologia 458 : 159 - 168.

Reagan, C.T. 1907. Report on a collection of fish from Nepal and the Western Himalayas. Records of Indian museum, Volume I : 157 - 158.

Ricker, W.E. 1968. Introduction to methods for assessment of fish production in freshwaters. In : Methods for assessment of fish production in freshwaters. (Ed. W.E.Ricker). International Biological Programme and Blackwell Scientific Publications, Oxford. pp 1 - 6.

Seber, G.A.F. and F.D. Le Cren 1967. Estimating population parameters from catches large relative to the population. Journal of Animal Ecology 36 : 631 - 643.

Sharma, C.K. 1977. River systems of Nepal. Ms. Sangeeta Sharma, Kathmandu,Nepal. 211 pp.

Shrestha, J. 1981. Fishes of Nepal. Curriculum Development Center, Tribhuvan University, Kathmandu. 318 pp.
Shrestha, J. 1994. Fish species in different water bodies of Nepal and their need for conservation. Ecoprint 1 (1) : $7-19$.

Shrestha, J. 2001. Taxonomic revision of fishes of Nepal. In: Environment and agriculture: Biodiversity, agriculture and pollution in South Asia. Eds. P.K. Jha, S.R. Baral, S.B. Karmacharya, H.D. Lekhak, P. Lacoul and C.B. Baniya. Ecological Society (ECOS), Kathmandu. pp 171-180.

Shrestha, T.K. 1981. Wildlife of Nepal: A study of renewable resources of Nepal Himalayas. Curriculum Development Center, Tribhuvan University, Kathmandu. 734 pp.

Shrestha, T.K. 1990. Resource ecology of the Himalayan waters. Curriculum Development Center, Tribhuvan University, Kathmandu. 645 pp.

Swar, D.B. 2005. The status of coldwater fish and fisheries in Nepal and prospects of their utilization for poverty reduction. In: Coldwater fisheries in the Transhimalayan countries. FAO Corporate Document Repository (FAO. Org/ doc rep / 005.

Swar, D.B. and T.B. Gurung 1988. Introduction and cage culture of exotic carps and their impact on fish harvested in Lake Begnas, Pokhara, Nepal. Hydrobiologia 166 : $277-283$.

Taft, A.C. 1955. A survey of fisheries in Nepal, both present potential, Kathmandu. Nepal-American Agriculture Cooperative Service, Kathmandu, Nepal. 44 pp.

*Terashima, A. 1984. Three new species of the cyprinoid genus Schizothorax from Lake Rara, North-western Nepal. Japanese Journal of Ichthyology 31 (2) : 122 135.

Thapa, R.B., and K.G. Rajbanshi 1968. Report on a few hill-stream fishes of Nepal. In : Proceedings of regional seminar on ecology of tropical highlands. UNESCO National Commission Kathmandu, Nepal. pp. 1-10.

Tripathi, M.P. 1985. Ecology of Pokhara valley. NepalNature's Paradise. (Ed. T.C. Majupuria). White Lotus Company, Bangkok. pp. 438-452.

Williams, L.R., C.S. Toepfer and A.D. Martinez 1996. The relationship between fish assemblages and environmental gradients in an Oklahoma Prairie Stream. Journal of Freshwater Ecology 11 (4) : 459 - 467. 